Abstracta Iranicacta Iranica

Revue bibliographique pour le domaine irano-aryen

Volume 30 | 2010

Comptes rendus des publications de 2007

\title{
"Worship According to the Yašts ». Iran, vol. XLV, 2007, pp.137-151.
}

\section{Samra Azarnouche}

\section{(2) OpenEdition}

10 Journals

\section{Édition électronique}

URL : http://journals.openedition.org/abstractairanica/37866

DOI : 10.4000/abstractairanica.37866

ISSN : 1961-960X

Éditeur :

CNRS (UMR 7528 Mondes iraniens et indiens), Éditions de l'IFRI

\section{Édition imprimée}

Date de publication : 8 avril 2010

ISSN : 0240-8910

\section{Référence électronique}

Samra Azarnouche, « "Worship According to the Yašts ». Iran, vol. XLV, 2007, pp.137-151. », Abstracta Iranica [En ligne], Volume 30 | 2010, document 198, mis en ligne le 08 avril 2010, consulté le 27

septembre 2020. URL : http://journals.openedition.org/abstractairanica/37866 ; DOI : https://doi.org/ 10.4000/abstractairanica.37866

Ce document a été généré automatiquement le 27 septembre 2020.

Tous droits réservés 


\section{"Worship According to the Yašts ». Iran, vol. XLV, 2007, pp.137-151.}

Samra Azarnouche 
1 Cet article consacré exclusivement aux Yašts applique une approche anthropologique à l'étude du sacrifice dans le matériel le plus récent de ces hymnes aux divinités du panthéon mazdéen. Bien que les allusions à la vie religieuse soient rares dans ces textes, l'A. tente d'établir une typologie du sacrifice en mettant au jour dans la mesure $\mathrm{du}$ possible l'essence du culte sacrificiel des Yašts, les conditions spatiales et temporelles, les indications sur le destinataire, le commanditaire et l'exécutant, la nature de l'offrande (oblation, libation...), ainsi que le but de l'offrande et la rétribution attendue.

2 En se référant aux idées de Heestermann (1993), l'A. affirme que, ce qu'en réalité Zoroastre dénonce dans le sacrifice est la forte ritualisation qu'il a subie, plutôt que l'acte en soi.

3 Cet article nous éclaire également sur les diverses théories concernant le principe de réciprocité entre le sacrifiant et la divinité.

4 Même si les thèmes dominants des Yašts restent la triade offrande-requêterécompense, il n'est pas aisé de se rendre compte de l'état réel de la pratique cultuelle, car ce que les Yašts véhiculent sont des représentations religieuses poétiques, non des réalités.

5 Quelques corrections sont nécessaires: p. 139, col.2 : corriger Yt.11.4 en Y.11.4 et Yt. 11.1 en Y.11.1; p. 142, col.1: corriger Yt.10.2 en Y.10.2 et Yt.9.22, 23 en Y.9.22, 23 ; p. 143, col.2 : corriger Yašt 14 en Yašt 17 ; page 145, col.1 : corriger Yt.11.4 en Y.11.4 et Yt. 10.6 en Y.10.6.

6 Les deux références suivantes peuvent s'avérer utiles comme compléments à cet article : E. Benveniste, "Sur la terminologie iranienne du sacrifice ", Journal Asiatique CCLII, 1965, fasc. 1, pp. 45-48., H.-P. Schmidt, « How to Kill a Sacrificial Victim », Studien zur Indologie und Iranistik, Band 22, 1999, pp. 119-129.

INDEX

Thèmes : 6.1. Zoroastrisme

\section{AUTEURS}

SAMRA AZARNOUCHE

Paris 